\title{
Response of Browallia speciosa Hook. and Thevetia peruviana (Pers.) K. Schum. Plants to Some Growing Media and Fertilization Treatments
}

\author{
Sayed M. Shahin and Abla H. Dergham \\ Botanical Gards Res. Dept., Hort. Res. Inst., ARC, Giza, Egypt.
}

\begin{abstract}
In order to get the best landscape value of Browallia speciosa Hook. and Thevetia peruviana (Pers) K. Schum. plants when used as pot plants the present study was conducted in a semi-shade place at the nursery of Orman Botanical Garden, Hort. Res. Inst., Giza, Egypt during 2016 and 2017 seasons, where one-year-old seedlings of the aforenamed two plant species were transplanted in 20 -cm-diameter plastic pots filled with about $3.5 \mathrm{~kg}$ of one of the following media: pure sand (as control) or sand supplemented with $25 \%(3: 1, \mathrm{v} / \mathrm{v})$ of either clay or farmyard manure (FYM). After 2 weeks from transplanting, the seedlings received 3 fertilization treatments as follows: ammonium sulphate $\left[(\mathrm{NH} 4)_{2} \mathrm{SO}_{4}, 20.5 \% \mathrm{~N}\right]$ at 2 $\mathrm{g} /$ plant, added monthly as soil drench for 5 times, and 2 forms of potassein [K-N $\left(30 \% \mathrm{~K}_{2} \mathrm{O}+8 \% \mathrm{~N}\right)$ and K-P $(30 \%$ $\left.\mathrm{K}_{2} \mathrm{O}+10 \% \mathrm{P}_{2} \mathrm{O}_{5}\right)$ ], added monthly for 5 times as foliar spray at $2 \mathrm{ml} / 1$ concentration for each. The effect of combined treatments between growing media and fertilization treatments was also studied.

The results of this study have shown that means of vegetative and root growth parameters (plant length, stem diameter, No. leaves/plant, root length and fresh and dry weights of leaves and roots) of the two studied plants were significantly increased in response to amending the sand with $25 \%(3: 1, \mathrm{v} / \mathrm{v})$ of either clay or FYM, as well fertilizing with either form of potassein, with the superiority of both sand $+25 \%(3: 1, \mathrm{v} / \mathrm{v}) \mathrm{FYM}$ growing media and K-N at $2 \mathrm{ml} / 1$ fertilization treatments, that gave the highest records in the two seasons. Thus, the best growth in both plants was attained by planting them in sand $+25 \%(3: 1, \mathrm{v} / \mathrm{v})$ FYM mixture and spraying their foliage with $2 \mathrm{ml} / 1 \mathrm{~K}-\mathrm{N}$ aqueous solution. A similar trend was also obtained concerning the leaf content of chlorophyll a, b, carotenoids, N, P and K, with few exceptions.

So, it can be recommended to planting the one-year-old seedlings of both Browallia speciosa and Thevetia peruviana in a mixture composed of sand $+25 \%(3: 1, \mathrm{v} / \mathrm{v}) \mathrm{FYM}$ and spraying their foliage with aqueous solution of potassein $\mathrm{N}$ at 2 $\mathrm{ml} / \mathrm{l}$ concentration, 5 times with one month interval to get model pot plants of high quality.
\end{abstract}

Key words: Browallia speciosa and Thevetia peruviana, growing media, sand, clay, FYM, potassein forms, ammonium sulphate.

\section{INTRODUCTION}

Some ornamental plants can be use for many purposes, among them may be Browallia and Thevetia. The former (Browallia speciosa Hook, Fam. Solanaceae) is a Colombian tall annual, with abundant striated, dark purple flowers, all solitary, auxillary, peduncle shorter than the leaves. The leaves oblong ovate, petioled, sometimes opposite, sometimes alternate. It can be grown in poorer soil than most half-hardy annuals and make excellent bedding plants. They are also used for winter decoration proved placing them near the glass, and frequently stopped in order to produce compact plants. The small potted plants should be grown more commonly by florists for home decoration at Christmas. It is even possible to lift flowering plants from the open before the first frost of autumn and pot them for conservatory decoration. In pots under trees, B. speciosa makes excellent bedding plants. Propagation by seeds and cuttings, which may be sown in the open border, but for early bloom, it is better to start them indoors in early spring and transplant into the open by May $15^{\text {th }}$. The seeds being sown in midsummer, earlier or later according to the size of the specimens desired. Large specimens are excellent for cutting (Bailey, 1976; Helmut, 1976).

The latter one is Thevetia peruviana (Pers.) K. Schum. (Fam. Apocynaceae). It is evergreen shrub, up to $9 \mathrm{~m}$ height; leaves nearly sessile, linear to linear-lanceolate, to $15 \mathrm{~cm}$ long and 6-6.5 mm wide, narrowly acuminate, dark green, glossy; flowers fragrant, yellow, to $5 \mathrm{~cm}$ across. Native to tropical America, propagated by cuttings and seeds. Thrives in rich sandy soil and will tolerate a few degrees of frost if banked with dry sand, used as solitary specimen and containerized small shrub (Bailey, 1976).

The good nutrition and using cheap organic alternative for high price peatmoss are considered one of the most important factors for producing containerized ornamental plants from commercial point of view. Moreover, peatmoss is jeopardized by its use as fuel or as growing medium (Nieto et al., 2016). So, much research has been performed during the last years to find high quality and low cost substances from different organic wastes to avoid peat using. Among of these researches are those detected by Marfa et al., (2002) who reported that cattle manure compost, forest waste compost, pine bark compost, Farm yard manure and raw coir 
were the best peat-substitutes for the best growth of Euonymus japonicus plans. Likewise, Wazir et al., (2004) found that amending the garden soil with leaf mould, FYM or greenfert composts recorded the maximum survival \%, plant height, stem thickness, No. branches and leaves/plant, leaf area, No. roots, root length and thickness, root weight and crown thickness in Schefflera actinophylla plants. Similar observations were also revealed by Abdel-Fattah et al., (2008) on Brassaia actinophylla, El-Sayed et al., (2013) on Euonymus japonicus, Nieto et al., (2016) on Lactua sativa, Burnett et al., (2016) on Poinsettia, Niluni et al., (2017) on Plectranthus amboinicus and Plectranthus "Nicoletta", Sax and Scharenbroch (2017) on Aronia melanocarpa and Acer saccharum and Massa et al., (2018) who noticed that the green compost derived from selected raw material was found to be a valuable growing medium for 30 and $50 \%$ peat volume replacing in geranium (Pelargonium zonale) cultivation.

Fertilizing pot plants usually leads to considerable growth and development responses because their roots are restricted inside the pot. In this regard, Shahin et al., (2007) elicited that spraying the foliage of Hibiscus rosa-sinensis transplants with $\mathrm{K}-\mathrm{N}+\mathrm{K}-\mathrm{P}$ at $5 \mathrm{ml} / \mathrm{l}$ for each gave the tallest plants, the highest No. branches and leaves/plant, the largest leaf area, the heaviest fresh and dry weights of leaves, stem and roots, the widest flower diameter and the highest content of chlorophyll a, b, carotenoids, N, P and K compared to the untreated transplants. Similarly, El-Sayed et al., (2008) observed that drenching Ficus macrocarpa var. Hawaii transplants grown in sand + loam + peatmoss $(1: 1: 1$, by volume) soil mixture with either NPK (1:1:1) compound fertilizer at 6 $\mathrm{g} /$ plant or spraying their foliage with $\mathrm{K}-\mathrm{N}$ at $6 \mathrm{~g} / \mathrm{l}$ greatly improved plant height, branch and leaf No./plant, root length, leaves, stem and roots fresh and dry weights, as well as pigments, total carbohydrates, $\mathrm{N}, \mathrm{P}$ and $\mathrm{K}$ concentrations in the leaves, with the dominance of NPK treatment that recorded the utmost high means in most cases of both seasons. Analogous results were also explored by El-Sayed et al., (2010) on Vinca roseacv. Major, Shahin et al., (2014) on Merremia dissecta and Alvarado Camarillo et al., (2018) on lisianthus.

The effect of combining between growing media and fertilization on growth and chemical composition of ornamentals was also studied by Hammad et al., (2005) whom revealed that connecting between planting carob (Ceratonia siliqua) seedlings in clay + compost mixture at a ratio of $1: 2, \mathrm{v} / \mathrm{v}$ and fertilizing with ammonium nitrate $(33.5 \% \mathrm{~N})$ at a rate of $6 \mathrm{~g} \mathrm{~N} / 25$-cm-diameter pot gave the highest values of plant height, stem diameter, No. leaves/plant, leaf area, fresh and dry weights of plant, as well as leaf content of total carbohydrates, N, P and K. Further, El-Sayed et al., (2009) affirmed that planting of Nephrolepis exaltata in peatmoss combining with $5 \mathrm{~g} / \mathrm{pot}$ nitrobien biofertilizer acquired the highest means of survival \%, plant height, No. leaves/plant, root length and aerial parts and roots fresh and dry weights, while contents of pigments and total carbohydrates reached maximal values by planting in sand + clay + peatmoss mixture, alone or in combination with $5 \mathrm{~g} /$ pot nitrobien, but for the percentages of $\mathrm{N}, \mathrm{P}$ and $\mathrm{K}$, this was attained by planting in sand +clay + spent murshroom compost mixture, solely or coupled with nitrobien at $5 \mathrm{~g} /$ pot. These findings were supported by those discovered by El-Sayed and El-Shal (2008) on Brassaia actinophylla, Shahin et al., (2012) on Brassaia actinophylla and Euonymus joponicus cv. Aureus, Sumathi et al., (2017) on anthurium var. Tropical and Mohamed (2018) on Areca palm (Dypsis cabadae).

However, the current work aims to find out the most proper growing medium and fertilization treatment for good performance of both Browallia speciosa and Thevetia peruviana plants when used as pot plants.

\section{MATERIALS AND METHODS}

Two independent pot experiments were undertaken in a semi-shade place at the nursery of Orman Botanical Garden, Hort. Res. Inst., Giza, Egypt through the two successive seasons of 2016 and 2017 in order to reveal the response of Browallia and Thevetia seedlings to some growing media, some fertilization treatments and their interactions when used as pot plants.

Thus, one-year-old seedlings of both Browallia speciosa Hook. at a length of 70-75 cm with 22-24 leaves and Thevetia peruviana (Pers.) K. Schum. at 22-25 cm length with 20-22 leaves were transplanted on first of April for every season in 20$\mathrm{cm}$-diameter plastic pots (one seedling / pot) filled with about $3.5 \mathrm{~kg}$ of one of the following media: sand without any amendments (as control), sand +25 $\%$ clay (v/v) and Sand $+25 \%(\mathrm{v} / \mathrm{v})$ farmyard manure (FYM). The physical and chemical properties of the sand and clay used in the two seasons were determined and listed in Table (a), while those of FYM are shown in Table (b).

After two weeks from transplanting (on Mid of April), three fertilization treatments were applied as follows:

1- Chemical fertilization with ammonium sulphate $\left[\left(\mathrm{NH}_{4}\right)_{2} \mathrm{SO}_{4}, 20.5 \% \mathrm{~N}\right]$ at the rate of $2 \mathrm{~g} /$ plant, as a recommended dose for good growth, added monthly as soil drench for five times (Shahin et al., 2012). 
Table a: The physical and chemical properties of the sand and clay used in 2016 and 2017 seasons.

\begin{tabular}{|c|c|c|c|c|c|c|c|c|c|c|c|c|c|c|}
\hline \multirow{2}{*}{ Soil type } & \multicolumn{3}{|c|}{ Particle size distribution (\%) } & \multirow{2}{*}{ S.P. } & \multirow{2}{*}{$\begin{array}{c}\text { E.C. } \\
(\mathrm{dS} / \mathrm{m})\end{array}$} & \multirow{2}{*}{$\mathbf{p H}$} & \multicolumn{4}{|c|}{ Cations (meq/L) } & \multicolumn{4}{|c|}{ Anions (Meq/L) } \\
\hline & elong & Silt & Clo & & & & & & $2+$ & $\mathbf{K}$ & $\mathrm{HCO}_{3}$ & & $\mathrm{CI}^{-}$ & $\mathrm{SO}^{-}$ \\
\hline & & & & & 3.31 & & 7.50 & & & .50 & & & $U$ & \\
\hline & & JJ.J & & & 2.19 & 7.9 & .93 & .33 & & .37 & 3.82 & & & 41.75 \\
\hline
\end{tabular}

Table b: The physical and chemical properties of farmyard manure (FYM) used in 2016 and 2017 seasons.

\begin{tabular}{|c|c|c|c|c|c|c|c|c|c|c|c|c|c|}
\hline \multicolumn{5}{|c|}{ Macro elements (\%) } & \multicolumn{4}{|c|}{ Micro elements (ppm) } & \multirow{2}{*}{$\begin{array}{l}\text { O.C. } \\
(\%)\end{array}$} & \multirow{2}{*}{$\begin{array}{c}\text { O.M. } \\
(\%)\end{array}$} & \multirow{2}{*}{$\begin{array}{c}\mathrm{C} / \mathrm{N} \\
\text { ratio }\end{array}$} & \multirow{2}{*}{$\mathbf{p H}$} & \multirow{2}{*}{$\begin{array}{c}\text { E.C. } \\
(\mathrm{dS} / \mathrm{m})\end{array}$} \\
\hline $\mathbf{N}$ & $\mathbf{P}$ & $\mathbf{K}$ & $\mathbf{C a}$ & $\mathrm{Mg}$ & $\mathbf{Z n}$ & $\mathbf{F e}$ & Mn & $\mathbf{C u}$ & & & & & \\
\hline 1.85 & 0.71 & 2.29 & 0.23 & 0.81 & 20.10 & 1620 & 330 & 54 & 23.28 & 25.80 & 12.58 & 7.81 & 3.50 \\
\hline
\end{tabular}

2- Aqueous solutions of either potassein-N (a liquid fertilizer contains $30 \% \mathrm{~K}_{2} \mathrm{O}$ and $8 \% \mathrm{~N}$ ) or potassein-P (a liquid fertilizer contains $30 \%$ $\mathrm{K}_{2} \mathrm{O}$ and $10 \% \mathrm{P}_{2} \mathrm{O}_{5}$ ), both produced by Ministry of Agriculture, Egypt at $2 \mathrm{ml} / 1$ concentration for each, added as foliar spray till the solution was run-off, five times with one month interval.

3- Each fertilization treatment was combined with each one of growing medium to form 9 interaction treatments.

The layout of the two experiments in both seasons was a complete randomized design in factorial experimental type, replicated trice, as each replicate contained 5 plants (Mead et al., 1993). The usual agricultural practices recommended for such plantation were achieved as grower did.

At the end of every season (on October, $15^{\text {th }}$ ), the following data were recorded for each plant: plant length $(\mathrm{cm})$, stem diameter $(\mathrm{cm})$, number of leaves/plant, root length $(\mathrm{cm})$, as well as leaves and roots fresh and dry weights $(\mathrm{g})$. In fresh leaf samples taken from the middle parts of both plants in the second season only, photosynthetic pigments (chlorophyll a, b and carotenoids, mg/g f.w.) were measured using the quick method of Yadava (1986), while in dry samples, the percentages of nitrogen, phosphorus and potassium were assessed according to the methods described by Black (1956), Luatanab and Olsen (1965) and Page et al., (1982), respectively.

Data were then tabulated and subjected to analysis of variance using program of SAS Institute (2009), which was followed by Duncan's New Multiple Range Test (Steel and Torrie, 1980) to compare significancy among the means of various treatments.

\section{RESULTS AND DISCUSSION}

Effect of growing media, fertilization treatments and their interactions on:

1- Vegetative and root growth parameters of both plants:

According to data presented in Tables from (1) to (8), it is clear that means of all vegetative and root growth traits, expressed as: plant length $(\mathrm{cm})$, stem diameter $(\mathrm{cm})$, No. of leaves/plant, root length $(\mathrm{cm})$, as well as fresh and dry weights $(\mathrm{g})$ of both leaves and roots in the two studied plants were markedly improved in response to amending the sand with either clay or FYM at the percent of $25 \%$, with the superiority of sand $+25 \%$ FYM medium, which gave the highest means in all characters mentioned above over pure sand and sand $+25 \%$ clay media, with significant differences in most cases of the two seasons. This may be attributed to the role of farmyard manure in improving fertility of the growing medium, as it has a high manurial value for plant growth (Nieto et al., 2016). It may improve soil structure and texture, increase cation exchange capacity, improve water holding capacity and nutrient retention and create a suitable environment for root proliferation and biomass growth (Sax and Scharenbroch, 2017). In this regard, Burnett et al., (2016) mentioned that growers who mix their growing substrates with organic compost that has high water holding and cation exchange capacity at percentages ranging from 20 to $50 \%$ produced high quality container plants of Begonia x semperflorems cultorum, Catharanthus roseus, Cyclamen persicum, Petunia x hybrida, Salvia farinacea and Poinsettia.

Likewise, Niluni et al., (2017) postulated that planting Plectranthus amboinicus and Plectranthus "Nicoletta" in Promix-BX ${ }^{\mathrm{TM}}$ growing medium amended with $20 \%$ of vermicasts had significantly high fresh weight and leaf area index compared to plants grown in medium amended with $20 \%$ of either K-humate or $\mathrm{N}_{20} \mathrm{P}_{20} \mathrm{~K}_{20}$. Mashinchian et al., (2017) declared that growth of Spathiphllum wallisii is much better in media containing $40 \%$ cocopeat and $60 \%$ peatmoss, while Leca (expanded clay) and Styrofoam can be used at $25 \%$ only because an excessive amount of them led to a change in the physical characteristics of the media and a drop in the growth rate of the plant. On Pelargonium zonale, Massa et al., (2018) indicated that applying the green compost at 30 and $50 \%$ as peat substitute was found to be a valuable in preparing growing medium used for improving growth and quality of such plant.

Similarly, the two forms of potassein (K-N and $\mathrm{K}-\mathrm{P}$ ) caused a clear improvement in all vegetative and root growth attributes stated before relative to 
the recommended dose of $\left(\mathrm{NH}_{4}\right)_{2} \mathrm{SO}_{4}(2 \mathrm{~g} /$ plant $)$ in both plant species with significant differences in most instances of the two seasons. However, the prevalence was for fertilizing with $\mathrm{K}-\mathrm{N}$ at $2 \mathrm{ml} / \mathrm{l}$, that recorded the utmost high values in both seasons. This may be a scribed to the function of potassium $\left(\mathrm{K}^{+}\right)$on cell division and elongation, proteins and carbohydrates formation, activating translocation of sugars and starch from leaves to plant organs and its role as co-factor for about 60 enzymatic systems involved in plant growth (Cakmak, 2005). It is also involved in stomatal regulation of transpiration and photosynthesis, photophosphorylation, transportation of photoassimilates from source tissues to sink ones via the phloem, turgor maintenance and stress tolerance (Alvarado-Camarillo, 2018). Including potassein forms with either $\mathrm{N}$ or $\mathrm{P}$ increases their beneficial effects, as the former $(\mathrm{N})$ is the main constituent of all proteins, nucleic acids and most structural and non-structural components of plant cells. The latter $(\mathrm{P})$ is involving in energy transfer process and in building of phospholipids and nucleic acids (Handreck and Black, 2002; Broschat, 2006).

The role of fertilizers in enhancing growth and quality of ornamentals was previously documented by Shahin et al., (2007) on Hibiscus rosa-sinensis, El-Sayed et al., (2008) on Ficus macrocarpa var. Hawaii and Abou-Dahab et al., (2008) who found that ammonium nitrate at the rate of $7 \mathrm{~g} /$ plant of Moluccella laevis scored the best values of plant length, No. branches/plant, stem diameter, No. leaves/plant, inflorescence stalk length and dry weight of plant, followed by the mixed fertilizer (Tamarind seed gum $(12 \mathrm{~g})+$ ammonium nitrate $(1.75 \mathrm{~g}) /$ plant and then organic manure at the rate of
$24 \mathrm{~g} /$ plant. On Merremia dissecta, Shahin et al., (2014) clarified that a combined treatment of $10 \mathrm{ml} / \mathrm{l}$ humic acid and $5 \mathrm{ml} / \mathrm{l} \mathrm{K}-\mathrm{N}$ resulted better growth than the recommended dose of NPK $(2: 1: 1)$ at 2 $\mathrm{g} /$ plant and than applying each fertilizer alone. Recently, Alvarado-Camarillo et al., (2018) observed that lisianthus plants grown in volcanic rock and fertigated with a $\mathrm{N} / \mathrm{K}$ balance of 2.14 exhibited taller stem and heavier stem dry weight than those fertigated with a balance of 4.29, and higher flower buds count and total dry weight than those fertigated with a balance of 1.43 or 4.29 . Furthermore, plants fertigated with a balance of 2.14 gave higher dry weight when $\mathrm{N}$ was reduced from 15 to $9 \mathrm{meq} / 1$ and $\mathrm{K}$ from 7 to $4.2 \mathrm{meq} / 1$, suggesting that lisianthus does not require high levels of these nutrients.

Interaction treatments also exert a pronounced effect on vegetative and root growth of both browallia and thevetia plants, where the interacting between planting in sand $+25 \%$ FYM growing mixture and fertilizing with either K-N or K-P at $2 \mathrm{ml} / 1$ for each, recorded the utmost high values in most measured parameters of the two plant species over all other interactions, with non significant differences among themselves in both seasons. However, the mastership was for combining between planting in sand $+25 \%$ FYM mixture and fertilizing with $\mathrm{K}-\mathrm{N}$ at $2 \mathrm{ml} / \mathrm{l}$ that gave the highest means in most cases of the two seasons. This may be due to lump the benefits of both FYM as a fertile and enhancer amendment for chemical and physical properties of the growing mixture and $\mathrm{K}-\mathrm{N}$ as a quick soluble fertilizer providing the plants with two main macro-elements ( $\mathrm{N}$ and $\mathrm{K}$ ) necessary for healthy growth.

Table 1: Effect of growing media, fertilization treatments and their interactions on plant length and stem diameter of Browallia speciosa Hook. plants during 2016 and 2017 seasons

\begin{tabular}{|c|c|c|c|c|c|c|c|c|}
\hline \multirow[b]{2}{*}{ Media } & \multicolumn{4}{|c|}{ Plant length $(\mathrm{cm})$} & \multicolumn{4}{|c|}{ Stem diameter $(\mathrm{cm})$} \\
\hline & $\begin{array}{c}\left.\mathrm{NH}_{4}\right)_{2} \mathrm{SO}_{4} \\
\text { (2g/plant) }\end{array}$ & $\begin{array}{c}\mathrm{K}-\mathrm{N} \\
(2 \mathrm{ml} / \mathrm{l})\end{array}$ & $\begin{array}{c}\text { K-P } \\
(2 \mathrm{ml} / \mathrm{l})\end{array}$ & Mean & $\begin{array}{c}\left.\mathrm{NH}_{4}\right)_{2} \mathrm{SO}_{4} \\
\text { (2g/plant) }\end{array}$ & $\begin{array}{c}\mathrm{K}-\mathrm{N} \\
(2 \mathrm{ml} / \mathrm{l})\end{array}$ & $\begin{array}{c}\text { K-P } \\
(2 \mathrm{ml} / \mathrm{l})\end{array}$ & Mean \\
\hline & \multicolumn{8}{|c|}{ First season: 2016} \\
\hline Sand (S) & $120.33 \mathrm{~g}$ & $129.13 \mathrm{e}$ & $124.76 \mathrm{f}$ & $124.74 \mathrm{c}$ & $0.55 \mathrm{c}$ & $0.64 \mathrm{ab}$ & $0.60 \mathrm{~b}$ & $0.60 \mathrm{~b}$ \\
\hline $\mathrm{S}+25 \%$ clay & $134.26 \mathrm{~d}$ & $143.50 \mathrm{~b}$ & $138.00 \mathrm{c}$ & $138.59 \mathrm{~b}$ & $0.61 \mathrm{~b}$ & $0.70 \mathrm{a}$ & $0.65 \mathrm{ab}$ & $0.65 \mathrm{a}$ \\
\hline $\mathrm{S}+25 \% \mathrm{FYM}$ & $143.48 b$ & $149.81 \mathrm{a}$ & $146.93 \mathrm{ab}$ & $146.74 \mathrm{a}$ & $0.60 \mathrm{~b}$ & $0.70 \mathrm{a}$ & $0.65 \mathrm{ab}$ & $0.65 \mathrm{a}$ \\
\hline \multirow[t]{2}{*}{ Mean } & $132.69 \mathrm{c}$ & $140.81 \mathrm{a}$ & $136.56 \mathrm{~b}$ & & $0.59 \mathrm{~b}$ & $0.68 \mathrm{a}$ & $0.63 b$ & \\
\hline & \multicolumn{8}{|c|}{ Second season: 2017} \\
\hline Sand (S) & $126.32 \mathrm{~g}$ & $135.50 \mathrm{e}$ & $129.48 \mathrm{f}$ & $130.43 \mathrm{c}$ & $0.56 \mathrm{c}$ & $0.67 \mathrm{ab}$ & $0.62 b$ & $0.62 b$ \\
\hline $\mathrm{S}+25 \%$ clay & $141.10 \mathrm{~d}$ & $148.76 \mathrm{c}$ & $145.00 \mathrm{~cd}$ & $144.95 b$ & $0.58 \mathrm{bc}$ & $0.75 \mathrm{a}$ & $0.66 \mathrm{ab}$ & $0.66 \mathrm{ab}$ \\
\hline $\mathrm{S}+25 \% \mathrm{FYM}$ & $150.00 \mathrm{~b}$ & $156.93 \mathrm{a}$ & $153.33 \mathrm{ab}$ & $153.42 \mathrm{a}$ & $0.63 \mathrm{~b}$ & $0.74 \mathrm{a}$ & $0.69 \mathrm{ab}$ & $0.69 \mathrm{a}$ \\
\hline Mean & $139.14 \mathrm{c}$ & $147.06 \mathrm{a}$ & $142.60 \mathrm{~b}$ & & $0.59 \mathrm{c}$ & $0.72 \mathrm{a}$ & $0.66 \mathrm{~b}$ & \\
\hline
\end{tabular}

Means followed by the same letter in a column or row don't differ significantly according to Duncan's New Multiple Range Test at $\mathrm{P}=5 \%$. 
Table 2: Effect of growing media, fertilization treatments and their interactions on plant length and stem diameter of Thevetia peruviana (Pers.) K. Schum. plants during 2016 and 2017 seasons

\begin{tabular}{llccccccc}
\hline & \multicolumn{3}{c}{ Plant length $\mathbf{( c m )}$} & \multicolumn{3}{c}{ Stem diameter (cm) } \\
\hline
\end{tabular}

Table 3: Effect of growing media, fertilization treatments and their interactions on number of leaves and root length of Browallia speciosa Hook. plants during 2016 and 2017 seasons

\begin{tabular}{lcccccccc}
\hline & \multicolumn{3}{c}{ Number of leaves/plant } & \multicolumn{3}{c}{ Root length (cm) } \\
\cline { 2 - 10 } \\
\cline { 2 - 10 }
\end{tabular}

Means followed by the same letter in a column or row don't differ significantly according to Duncan's New Multiple Range Test at $\mathrm{P}=5 \%$.

Table 4: Effect of growing media, fertilization treatments and their interactions on number of leaves and root length of Thevetia peruviana (Pers.) K. Schum. plants during 2016 and 2017 seasons

\begin{tabular}{|c|c|c|c|c|c|c|c|c|}
\hline \multirow{2}{*}{ Media } & \multicolumn{4}{|c|}{ Number of leaves/plant } & \multicolumn{4}{|c|}{ Root length (cm) } \\
\hline & $\begin{array}{c}\text { (NH4)2SO4 } \\
\text { (2g/plant) }\end{array}$ & $\begin{array}{c}\mathrm{K}-\mathrm{N} \\
(2 \mathrm{ml} / \mathrm{l}) \\
\end{array}$ & $\begin{array}{c}\text { K-P } \\
(2 \mathrm{ml} / \mathrm{l}) \\
\end{array}$ & Mean & $\begin{array}{c}\text { (NH4)2SO4 } \\
\text { (2g/plant) }\end{array}$ & $\begin{array}{c}\mathrm{K}-\mathrm{N} \\
(2 \mathrm{ml} / \mathrm{l}) \\
\end{array}$ & $\begin{array}{c}\mathrm{K}-\mathrm{P} \\
(2 \mathrm{ml} / \mathrm{l}) \\
\end{array}$ & Mean \\
\hline & \multicolumn{8}{|c|}{ First season: 2016} \\
\hline Sand (S) & $39.00 \mathrm{e}$ & $47.31 \mathrm{~d}$ & $45.00 \mathrm{~d}$ & $43.77 \mathrm{c}$ & $19.50 \mathrm{e}$ & $21.58 \mathrm{~d}$ & $20.00 \mathrm{de}$ & $20.36 \mathrm{~b}$ \\
\hline $\mathrm{S}+25 \%$ clay & $47.96 \mathrm{~d}$ & $63.15 b$ & $51.76 \mathrm{~cd}$ & $54.29 b$ & $23.49 \mathrm{~cd}$ & $27.35 b$ & $25.88 \mathrm{bc}$ & $25.57 \mathrm{ab}$ \\
\hline$\underline{\mathrm{S}+25 \% \mathrm{FYM}}$ & $55.12 \mathrm{c}$ & $81.53 \mathrm{a}$ & $63.78 \mathrm{~b}$ & $66.81 \mathrm{a}$ & $25.00 \mathrm{c}$ & $30.46 \mathrm{a}$ & $27.10 \mathrm{~b}$ & $27.52 \mathrm{a}$ \\
\hline \multirow[t]{2}{*}{ Mean } & $47.36 \mathrm{c}$ & $64.00 \mathrm{a}$ & $53.51 \mathrm{~b}$ & & $22.66 \mathrm{c}$ & $26.46 \mathrm{a}$ & $24.33 b$ & \\
\hline & \multicolumn{8}{|c|}{ Second season: 2017} \\
\hline Sand (S) & $40.91 \mathrm{~d}$ & $49.35 \mathrm{~d}$ & $44.50 \mathrm{e}$ & $44.92 \mathrm{c}$ & $21.45 \mathrm{e}$ & $23.70 \mathrm{~d}$ & $21.00 \mathrm{e}$ & $22.05 \mathrm{c}$ \\
\hline$\underline{\mathrm{S}}+25 \%$ clay & $50.30 \mathrm{~d}$ & $65.10 \mathrm{~b}$ & $53.07 \mathrm{~cd}$ & $56.16 \mathrm{~b}$ & $25.00 \mathrm{~cd}$ & $28.81 \mathrm{~b}$ & $26.93 \mathrm{c}$ & $26.91 \mathrm{~b}$ \\
\hline $\mathrm{S}+25 \% \mathrm{FYM}$ & $57.67 \mathrm{c}$ & $80.73 a$ & $66.15 b$ & $68.18 \mathrm{a}$ & $26.31 \mathrm{c}$ & $32.17 \mathrm{a}$ & $28.32 \mathrm{~b}$ & $28.93 a$ \\
\hline Mean & $49.63 \mathrm{~d}$ & $65.06 \mathrm{a}$ & $54.57 \mathrm{~b}$ & & $24.26 \mathrm{c}$ & $28.23 \mathrm{a}$ & $25.42 \mathrm{~b}$ & \\
\hline
\end{tabular}


Table 5: Effect of growing media, fertilization treatments and their interactions on leaves and roots fresh weight of Browallia speciosa Hook. plants during 2016 and 2017 seasons.

\begin{tabular}{l}
\hline \multicolumn{3}{c}{ Leaves fresh weight (g) } \\
\cline { 2 - 9 }
\end{tabular}

Table 6: Effect of growing media, fertilization treatments and their interactions on leaves and roots fresh weight of Thevetia peruviana (Pers.) K. Schum. plants during 2016 and 2017 seasons.

\begin{tabular}{|c|c|c|c|c|c|c|c|c|}
\hline \multirow{2}{*}{ Media } & \multicolumn{4}{|c|}{ Leaves fresh weight (g) } & \multicolumn{4}{|c|}{ Roots fresh weight (g) } \\
\hline & $\begin{array}{c}\text { (NH4)2SO4 } \\
\text { (2g/plant) }\end{array}$ & $\begin{array}{c}\mathrm{K}-\mathrm{N} \\
(2 \mathrm{ml} / \mathrm{l})\end{array}$ & $\begin{array}{c}\mathrm{K}-\mathrm{P} \\
(2 \mathrm{ml} / \mathrm{l})\end{array}$ & Mean & $\begin{array}{c}\text { (NH4)2SO4 } \\
\text { (2g/plant) }\end{array}$ & $\begin{array}{c}\mathrm{K}-\mathrm{N} \\
(2 \mathrm{ml} / \mathrm{l})\end{array}$ & $\begin{array}{c}\text { K-P } \\
(2 \mathrm{ml} / \mathrm{l})\end{array}$ & Mean \\
\hline & \multicolumn{8}{|c|}{ First season: 2016} \\
\hline Sand (S) & $7.90 \mathrm{~d}$ & $10.67 \mathrm{c}$ & $8.98 \mathrm{~cd}$ & $9.18 \mathrm{c}$ & $6.35 \mathrm{c}$ & $6.78 \mathrm{c}$ & $6.59 \mathrm{c}$ & $6.57 \mathrm{c}$ \\
\hline $\mathrm{S}+25 \%$ clay & $10.78 \mathrm{c}$ & $13.74 b$ & $11.16 \mathrm{bc}$ & $11.89 \mathrm{~b}$ & $7.76 \mathrm{bc}$ & $8.57 \mathrm{~b}$ & $8.14 \mathrm{~b}$ & $8.16 \mathrm{~b}$ \\
\hline $\mathrm{S}+25 \% \mathrm{FYM}$ & $12.38 \mathrm{bc}$ & $17.73 \mathrm{a}$ & $13.75 \mathrm{~b}$ & $14.62 \mathrm{a}$ & $8.10 \mathrm{~b}$ & $9.65 \mathrm{a}$ & $8.79 \mathrm{ab}$ & $8.85 \mathrm{a}$ \\
\hline \multirow[t]{2}{*}{ Mean } & $10.35 \mathrm{~b}$ & $14.05 \mathrm{a}$ & $11.30 \mathrm{~b}$ & & $7.40 \mathrm{~b}$ & $8.34 \mathrm{a}$ & $7.84 \mathrm{ab}$ & \\
\hline & \multicolumn{8}{|c|}{ Second season: 2017} \\
\hline Sand (S) & $7.79 \mathrm{de}$ & $11.15 \mathrm{c}$ & $9.51 \mathrm{~d}$ & $9.48 \mathrm{c}$ & $5.97 \mathrm{~d}$ & $7.15 \mathrm{c}$ & $6.95 \mathrm{c}$ & $6.69 \mathrm{c}$ \\
\hline $\mathrm{S}+25 \%$ clay & $10.36 \mathrm{c}$ & $14.39 \mathrm{~b}$ & $11.80 \mathrm{bc}$ & $12.18 \mathrm{~b}$ & $7.83 \mathrm{bc}$ & $9.10 \mathrm{~b}$ & $8.55 \mathrm{~b}$ & $8.49 \mathrm{~b}$ \\
\hline $\mathrm{S}+25 \% \mathrm{FYM}$ & $12.58 \mathrm{bc}$ & $18.50 \mathrm{a}$ & $14.47 \mathrm{~b}$ & $15.18 \mathrm{a}$ & $8.51 \mathrm{~b}$ & $10.13 a$ & $9.30 \mathrm{ab}$ & $9.31 \mathrm{a}$ \\
\hline Mean & $10.24 \mathrm{c}$ & $14.68 \mathrm{a}$ & $11.93 \mathrm{~b}$ & & $7.44 \mathrm{~b}$ & $8.79 \mathrm{a}$ & $8.27 \mathrm{ab}$ & \\
\hline
\end{tabular}

Means followed by the same letter in a column or row don't differ significantly according to Duncan's New Multiple Range Test at $\mathrm{P}=5 \%$.

Table 7: Effect of growing media, fertilization treatments and their interactions on leaves $\mathrm{N}$ and roots dry weight of Browallia speciosa Hook. plants during 2016 and 2017 seasons.

\begin{tabular}{|c|c|c|c|c|c|c|c|c|}
\hline \multirow{2}{*}{ Media } & \multicolumn{4}{|c|}{ Leaves dry weight (g) } & \multicolumn{4}{|c|}{ Roots dry weight (g) } \\
\hline & $\begin{array}{l}\text { (H4)2SO4 } \\
\text { (2g/plant) } \\
\end{array}$ & $\begin{array}{c}\mathrm{K}-\mathrm{N} \\
(2 \mathrm{ml} / \mathrm{l}) \\
\end{array}$ & $\begin{array}{c}\mathrm{K}-\mathrm{P} \\
(2 \mathrm{ml} / \mathrm{l}) \\
\end{array}$ & Mean & $\begin{array}{c}\text { (NH4)2SO4 } \\
\text { (2g/plant) }\end{array}$ & $\begin{array}{c}\mathrm{K}-\mathrm{N} \\
(2 \mathrm{ml} / \mathrm{l}) \\
\end{array}$ & $\begin{array}{c}\mathrm{K}-\mathrm{P} \\
(2 \mathrm{ml} / \mathrm{l}) \\
\end{array}$ & Mean \\
\hline & \multicolumn{8}{|c|}{ First season: 2016} \\
\hline Sand (S) & $0.81 \mathrm{c}$ & $1.07 \mathrm{c}$ & $0.93 \mathrm{c}$ & $0.94 \mathrm{~b}$ & $1.28 \mathrm{c}$ & $1.55 \mathrm{c}$ & $1.43 \mathrm{c}$ & $1.42 \mathrm{~b}$ \\
\hline $\mathrm{S}+25 \%$ clay & $1.43 \mathrm{bc}$ & $1.68 \mathrm{bc}$ & $1.50 \mathrm{bc}$ & $1.54 \mathrm{~b}$ & $1.58 \mathrm{bc}$ & $1.85 \mathrm{bc}$ & $1.76 \mathrm{bc}$ & $1.73 b$ \\
\hline$\underline{\mathrm{S}+25 \% \mathrm{FYM}}$ & $1.87 \mathrm{bc}$ & $3.79 \mathrm{a}$ & $2.26 \mathrm{~b}$ & $2.64 \mathrm{a}$ & $2.37 \mathrm{~b}$ & $3.27 \mathrm{a}$ & $2.38 \mathrm{~b}$ & $2.67 \mathrm{a}$ \\
\hline \multirow[t]{2}{*}{ Mean } & $1.37 \mathrm{~b}$ & $2.18 \mathrm{a}$ & $1.56 \mathrm{~b}$ & & $1.74 \mathrm{~b}$ & $2.23 \mathrm{a}$ & $1.86 \mathrm{~b}$ & \\
\hline & \multicolumn{8}{|c|}{ Second season: 2017} \\
\hline Sand (S) & $0.86 \mathrm{c}$ & $1.13 \mathrm{c}$ & $0.98 \mathrm{c}$ & $0.99 \mathrm{~b}$ & $1.35 \mathrm{c}$ & $1.63 \mathrm{c}$ & $1.51 \mathrm{c}$ & $1.50 \mathrm{~b}$ \\
\hline$\underline{\mathrm{S}+25 \% \text { clay }}$ & $1.50 \mathrm{bc}$ & $1.80 \mathrm{bc}$ & $1.61 \mathrm{bc}$ & $1.64 \mathrm{~b}$ & $1.70 \mathrm{bc}$ & $1.96 \mathrm{bc}$ & $1.85 \mathrm{bc}$ & $1.84 \mathrm{~b}$ \\
\hline$\underline{\mathrm{S}+25 \% \mathrm{FYM}}$ & $2.00 \mathrm{~b}$ & $4.00 \mathrm{a}$ & $2.50 \mathrm{~b}$ & $2.83 \mathrm{a}$ & $2.50 \mathrm{~b}$ & $3.47 \mathrm{a}$ & $2.56 \mathrm{~b}$ & $2.84 \mathrm{a}$ \\
\hline Mean & $1.45 \mathrm{~b}$ & $2.31 \mathrm{a}$ & $1.70 \mathrm{~b}$ & & $1.85 \mathrm{~b}$ & $2.35 \mathrm{a}$ & $1.97 \mathrm{~b}$ & \\
\hline
\end{tabular}


Table 8: Effect of growing media, fertilization treatments and their interactions on leaves and roots dry weight of Thevetia peruviana (Pers.) K. Schum. plants during 2016 and 2017 seasons.

\begin{tabular}{|c|c|c|c|c|c|c|c|c|}
\hline \multirow{2}{*}{$\begin{array}{l}\text { Fertilization } \\
\text { treatments } \\
\text { Media }\end{array}$} & \multicolumn{4}{|c|}{ Leaves dry weight (g) } & \multicolumn{4}{|c|}{ Roots dry weight (g) } \\
\hline & $\begin{array}{c}\text { (NH4)2SO4 } \\
\text { (2g/plant) }\end{array}$ & $\begin{array}{c}\mathrm{K}-\mathrm{N} \\
(2 \mathrm{ml} / \mathrm{l}) \\
\end{array}$ & $\begin{array}{c}\mathrm{K}-\mathrm{P} \\
(2 \mathrm{ml} / \mathrm{l}) \\
\end{array}$ & Mean & $\begin{array}{c}\text { (NH4)2SO4 } \\
\text { (2g/plant) }\end{array}$ & $\begin{array}{c}\mathrm{K}-\mathrm{N} \\
(2 \mathrm{ml} / \mathrm{l}) \\
\end{array}$ & $\begin{array}{c}\mathrm{K}-\mathrm{P} \\
(2 \mathrm{ml} / \mathrm{l}) \\
\end{array}$ & Mean \\
\hline & \multicolumn{8}{|c|}{ First season: 2016} \\
\hline Sand (S) & $2.31 \mathrm{c}$ & $3.20 \mathrm{bc}$ & $2.68 \mathrm{c}$ & $2.73 c$ & $3.48 \mathrm{c}$ & $3.73 b c$ & $3.61 \mathrm{c}$ & $3.61 \mathrm{~b}$ \\
\hline $\mathrm{S}+25 \%$ clay & $3.25 \mathrm{bc}$ & $4.15 b$ & $3.35 \mathrm{bc}$ & $3.58 \mathrm{~b}$ & $4.23 b$ & $4.73 \mathrm{ab}$ & $4.46 \mathrm{~b}$ & $4.47 \mathrm{ab}$ \\
\hline $\mathrm{S}+25 \% \mathrm{FYM}$ & $3.72 \mathrm{bc}$ & $5.31 \mathrm{a}$ & $4.10 \mathrm{~b}$ & $4.38 \mathrm{a}$ & $4.41 \mathrm{~b}$ & $5.31 \mathrm{a}$ & $4.73 \mathrm{ab}$ & $4.82 \mathrm{a}$ \\
\hline \multirow[t]{2}{*}{ Mean } & $3.09 \mathrm{~b}$ & $4.22 \mathrm{a}$ & $3.38 \mathrm{~b}$ & & $4.04 \mathrm{~b}$ & $4.59 \mathrm{a}$ & $4.27 \mathrm{ab}$ & \\
\hline & \multicolumn{8}{|c|}{ Second season: 2017} \\
\hline Sand (S) & $2.37 \mathrm{c}$ & $3.36 \mathrm{bc}$ & $2.59 \mathrm{c}$ & $2.77 \mathrm{c}$ & $3.50 \mathrm{c}$ & $3.89 \mathrm{bc}$ & $3.50 \mathrm{c}$ & $3.63 \mathrm{~b}$ \\
\hline$\underline{\mathrm{S}+25 \% \text { clay }}$ & $3.41 \mathrm{bc}$ & $4.37 \mathrm{~b}$ & $3.41 \mathrm{bc}$ & $3.73 b$ & $4.45 \mathrm{~b}$ & $4.95 \mathrm{ab}$ & $4.70 \mathrm{~b}$ & $4.70 \mathrm{ab}$ \\
\hline $\mathrm{S}+25 \% \mathrm{FYM}$ & $3.90 \mathrm{bc}$ & $5.50 \mathrm{a}$ & $4.33 b$ & $4.58 \mathrm{a}$ & $4.61 \mathrm{~b}$ & $5.60 \mathrm{a}$ & $4.93 \mathrm{ab}$ & $5.05 \mathrm{a}$ \\
\hline Mean & $3.23 \mathrm{~b}$ & $4.41 \mathrm{a}$ & $3.44 \mathrm{~b}$ & & $4.19 \mathrm{~b}$ & $4.81 \mathrm{a}$ & $4.38 \mathrm{~b}$ & \\
\hline
\end{tabular}

Means followed by the same letter in a column or row don't differ significantly according to Duncan's New Multiple Range Test at $\mathrm{P}=5 \%$.

These gains are supported by the results of Shahin et al., (2012) who revealed that planting Brassaia actinophylla and Euonymus japonicus transplants in sand $+25 \%$ FYM mixture and fertilizing them with Kristalon (2g/plant) + active dry yeast $(5 \mathrm{~g} / \mathrm{l})$ acquired better vegetative and root growth accompanied with higher quality. On cut flowers of anthurium var. Tropical, Sumathi et al., (2017) reported that flowers produced from plants cultivated in coconut husk + charcoal $(3: 1)$ as growing media along with foliar spray of NPK (12:61:40) at $2 \%$ showed maximum water uptake, fresh weight retention and increased vase life compared to other combinations. In addition, Mohamed (2018) decided that growing Dypysis cabadae palm plants in a mixture of compost + peatmoss + perlite $(1: 1: 1$, by volume) supplemented with kristalon at $8 \mathrm{~g} /$ pot produced the tallest plant, the heaviest fresh and dry weights of leaves and stem/plant, the longest stem and root lengths and the heaviest roots fresh and dry weights. Besides, the highest No. leaves/plant, stem diameter, plant width and No. roots/plant. However, the greatest show value of such palm as pot plant was attained by using the mixture composed of clay + sand + compost + peatmoss + perlite + kristalon at $8 \mathrm{~g} /$ pot.

\section{2- Chemical constituents contents in the leaves of}

both plants:

A similar trend to that of vegetative and root growth characters was also obtained regarding the effect of different treatments employed in this study on chemical composition of the leaves in the two tested plants, where fortifying the sand with $25 \%$ of either clay or farmyard manure markedly improved concentrations of chlorophyll $\mathrm{a}, \mathrm{b}$ and carotenoids (mg/g f.w.) and the percentages of N, P and $\mathrm{K}$ in the leaves of both plants (Tables, 9 and 10), and the upper hand was also for sand $+25 \%$ FYM mixture which gave the highest records at all. These findings may indicate the role of FYM in improving fertility of the growing mixture and supplying the plants slowly with more nutrients necessary for good growth. In this respect, Gonzalez and Cooperband (2003) pointed out that duck manure increased total soil content of $\mathrm{C}, \mathrm{N}, \mathrm{P}$ and $\mathrm{Cu}$, as well as available $\mathrm{P}, \mathrm{S}, \mathrm{Ca}, \mathrm{Mg}, \mathrm{K}$ and $\mathrm{Zn}$. On Euonymus japonicus cv. Aureus, El-Sayed et al., (2013) revealed that amending the sand with olive meal compost, soybean meal compost and broad bean hulls compost at equal ports greatly increased chlorophyll a, b, carotenoids, total sugars, N, P and $\mathrm{K}$ in the leaves compared to plants grown in pure sand. Besides, Massa et al., (2018) indicated that applying the green compost at 30 or $50 \%$ to the growing medium of Pelargonium zonale raised $\mathrm{N}$, $\mathrm{P}, \mathrm{K}, \mathrm{Ca}, \mathrm{Mg}$ and $\mathrm{Zn}$ in the leaves compared with planting in peat only.

The two forms of potassein fertilizer are also increased content of the previous chemical components in the leaves of both plants except for carotenoids content which was declined as a result of dressing with such potassein forms relative to (NH4) ${ }_{2} \mathrm{SO}_{4}$ treatment. In general, $\mathrm{K}-\mathrm{N}$ achieved, to some extent better results than K-P, giving higher contents of aforenamed constituents, with the exception of P content, as K-P form resulted higher concentration of such element in the leaves of both plants. These results are in accordance with those pointed out by Shahin et al., (2007) on Hibiscus rosa-sinensis, El-Sayed et al. (2010) on Vinca rosea cv. Major, Shahin et al., (2014) on Merremia dissecta and Alvarado Camarillo et al., (2018) whom suggested that $\mathrm{N} / \mathrm{K}$ balance of 2.14 in substrate solution increased $\mathrm{N}$ concentration in the shoot of lisianthus plants, which was associated with higher $\mathrm{P}$ and $\mathrm{Mg}$ in the plant tissues. Shoot K concentration significantly increased when the $\mathrm{N} / \mathrm{K}$ balance decreased due to the higher concentration of external $\mathrm{K}$ when the balance decreased. 
The chemical composition of the studied plants leaves was markedly affected by the combined treatments, where interacting between planting in sand fortified with $25 \%$ FYM and fertilizing with either form of potassein registered the higher content of various constituents measured in this study than the other interactions, with the dominance of $\mathrm{S}+25 \% \mathrm{FYM}$ and $2 \mathrm{ml} / \mathrm{K}-\mathrm{N}$ combination that recorded the utmost high values of measured components, except for $\mathrm{P}$ values that reached maximum by planting in the same growing mixture and dressing with $\mathrm{K}-\mathrm{P}$ at $2 \mathrm{ml} / \mathrm{l}$. These gains may be reasonable due to lumping the positive effects of FYM as a slow release organic source supplying the plants continuously with minerals and potassein forms that save N, P and K luxuriously for the plants. In this connection, Shahin et al., (2012) declared that combining between kristalon $(2 \mathrm{~g} /$ plant $)+$ active dry yeast $(5 \mathrm{~g} / \mathrm{l})$ and planting in the sand strengthened with $25 \%$ FYM elevated concentrations of chlorophyll a, b, carotenoids, N, P and $\mathrm{K}$ in the leaves of both Brassaia actinophylla and Euonymus japonicus transplants to the maximal averages. Moreover, Sumathi et al., (2017) found that flowers produced from anthurium var. Tropical plants cultivated in coconut husk + charcoal mixture and foliar sprayed with $12 \mathrm{~N}: 61 \mathrm{P}: 40 \mathrm{~K}$ at $0.2 \%$ contained the highest total soluble sugars in their leaves. Recently, Mohamed (2018) postulated that growing Dypsis cabadae palm plants in compost + peatmoss + prelite $(1: 1: 1, \quad \mathrm{v} / \mathrm{v} / \mathrm{v})$ mixture supplemented with $8 \mathrm{~g} /$ pot kristalon produced the highest total chlorophylls, carbohydrates, N, P, K, auxin, gibberellins and cytokinins with the lowest leaf abscisic acid content.

From the aforementioned results, it is advised to growing one-year-old seedlings of either Browallia speciosa or Thevetia peruviana in a mixture of sand $+25 \%$ FYM and spraying their foliage with potassein $-\mathrm{N}$ at $2 \mathrm{ml} / \mathrm{l}$ concentration to obtain picturesque and healthy specimens used as pot plants.

Table 9: Effect of growing media, fertilization treatments and their interactions on some chemical constituents contents in Browallia speciosa Hook. leaves during 2017 season.

\begin{tabular}{|c|c|c|c|c|c|c|c|c|c|c|c|c|}
\hline \multirow[b]{2}{*}{$\begin{array}{l}\text { Fertilization } \\
\text { treatments } \\
\text { Media }\end{array}$} & \multicolumn{4}{|c|}{ Chlorophyll a (mg/g f.w.) } & \multicolumn{4}{|c|}{ Chlorophyll b (mg/g f.w.) } & \multicolumn{4}{|c|}{ Carotenoids (mg/g f.w.) } \\
\hline & $\begin{array}{l}\left(\mathrm{NH}_{4}\right)_{2} \mathrm{SO}_{4} \\
(2 \mathrm{~g} / \text { plant }) \\
\end{array}$ & $\begin{array}{l}\mathrm{K}-\mathrm{N} \\
(2 \mathrm{ml} / \mathrm{l}) \\
\end{array}$ & K-P & Mean & $\begin{array}{c}\left(\mathrm{NH}_{4}\right)_{2} \mathrm{SO}_{4} \\
(2 \mathrm{~g} / \text { plant })\end{array}$ & $\begin{array}{c}\mathrm{K}-\mathrm{N} \\
(2 \\
\mathrm{ml} / \mathrm{l}) \\
\end{array}$ & $\begin{array}{c}\mathrm{K}-\mathrm{P} \\
(2 \mathrm{ml} / \mathrm{l}) \\
\end{array}$ & & $\begin{array}{c}\left(\mathrm{NH}_{4}\right)_{2} \mathrm{SO}_{4} \\
(2 \mathrm{~g} / \text { plant })\end{array}$ & $\begin{array}{c}\mathrm{K}-\mathrm{N} \\
(2 \\
\mathrm{ml} / \mathrm{l}) \\
\end{array}$ & $\begin{array}{c}\text { K-P } \\
(2 \mathrm{ml} / \mathrm{l}) \\
\end{array}$ & ean \\
\hline nd $(S)$ & 0.707 & 0.792 & 0.725 & 0.741 & 0.284 & 0.345 & 0.312 & 0.314 & 0.347 & 0.282 & 0.268 & 0.299 \\
\hline$+25 \%$ clay & 0.935 & 1.014 & 0.964 & 0.971 & 0.365 & 0.405 & 0.399 & 0.390 & 0.387 & 0.392 & 0.388 & 0.389 \\
\hline $\mathrm{S}+25 \% \mathrm{FYM}$ & 1.036 & 1.403 & 1.028 & 1.156 & 0.431 & 0.533 & 0.432 & 0.465 & 0.524 & 0.461 & 0.455 & 0.480 \\
\hline \multirow[t]{2}{*}{ Mean } & 0.893 & 1.070 & 0.906 & & 0.360 & 0.428 & 0.381 & & 0.419 & 0.378 & 0.370 & \\
\hline & \multicolumn{4}{|c|}{$\mathbf{N}(\%)$} & \multicolumn{4}{|c|}{$\mathbf{P}(\%)$} & \multicolumn{4}{|c|}{ K (\%) } \\
\hline Sand (S) & 1.756 & 2.126 & 1.581 & 1.821 & 0.078 & 0.081 & 0.104 & 0.088 & 1.567 & 1.727 & 1.688 & 1.660 \\
\hline $\mathrm{S}+25 \%$ clay & 1.897 & 2.101 & 1.703 & 1.900 & 0.085 & 0.097 & 0.117 & 0.100 & 1.763 & 1.907 & 1.896 & 1.855 \\
\hline$S+25 \% \mathrm{FYM}$ & 2.312 & 2.396 & 2.076 & 2.261 & 0.107 & 0.099 & 0.133 & 0.113 & 2.031 & 2.233 & 2.118 & 2.127 \\
\hline Mean & 1.988 & 2.208 & 1.787 & & 0.090 & 0.092 & 0.118 & & 1.787 & 1.955 & 1.901 & \\
\hline
\end{tabular}

Table 10: Effect of growing media, fertilization treatments and their interactions on some chemical constituents contents in Thevetia peruviana (Pers.) K. Schum. leaves during 2017 season.

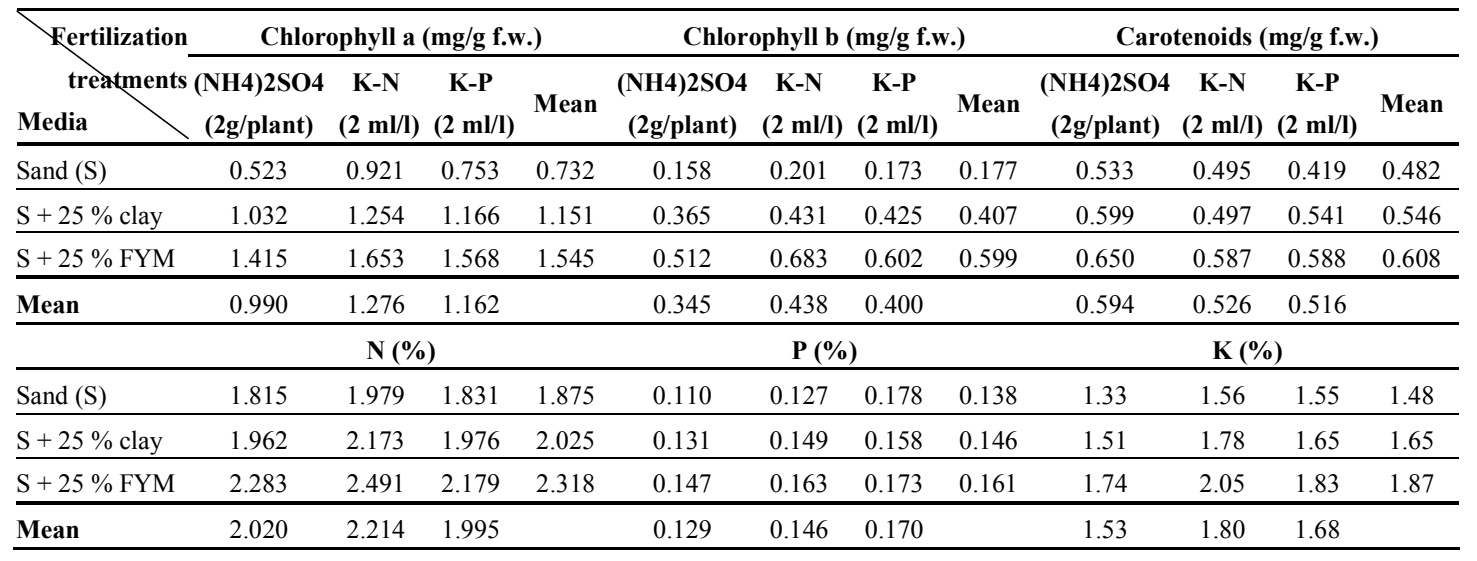




\section{REFERENCES}

Abdel-Fattah, Gehan, H.;Rezk-Alla, B.B. and ElFouly, Amal, S. (2008). Effect of some organic additives to sand on growth and chemical composition of Brassaia actinophylla (Endl) Harms plant. Ann. Agric. Sci., Moshtohor, 46 (4): 477-482.

Abou-Dahab, M.A.; Habib, Afaf, M. and Saleh, S.M. (2008). Effect of organic and chemical fertilization on growth of Moluccella laevis plants. Egypt. J. Appl. Sci., 23 (6A): 311-325.

Alvarado-Camarillo, D.; Castillo-Gonzalez, A.M.; Valdez-Aguilar, L. A. and Garcia-Santiago, J.C. (2018). Balance and concentration of nitrogen and potassium affect growth and nutrient status in soiless cultivated lisianthus. Acta Agric. Sandinavica (Soil \& Plant Sci.), 68 (6): 496-504.

Bailey, L. H. (1976). Hortus Third, Macmillan Publishing Co., Inc., 866 Third Avenue, New York, N.Y. 10022.1290 pp.

Black, C. A. (1956). Methods of Soil Analysis, Part I and II. Amer. Soc. Agron. In Publ., Madison, Wise, U.S.A.

Broschat, T.K. (2006). Effect of phosphorus and phosphoric acid on growth and phosphorus concentration in container grown tropical ornamental plants. HortTech., 16 (10): 105-108.

Burnett, E.; Mattson, N.S. and Williams, K. A. (2016). Substrates and fertilizers for organic container production of herbs, vegetables and herbaceous ornamental plants grown in greenhouses in the United States. Scientia Hort., 208: 111-119.

Cakmak, I. (2005). The role of potassium in alleviating detrimental effects of abiotic stresses in plants. J. Plant Nutr. Soil Sci., 168: 521-530.

El-Sayed, Boshra, A.; Ahmed, Samira, S. and Shahin, S.M. (2010). Response of Vinca rosea $c v$. Major plant to chemical and biofertiliztion treatments. J. Biol. Chem. \& Environ., Sci., 5 (4): 25-38.

El-Sayed, Boshra, A.; El-Din, Hanan, A. and Shahin, S.M. (2009). Response of Nephrolepis exaltata Schatt. plant to medium type and nitrobien biofertilization. J. Biol. Chem. \& Environ., Sci., 4 (1): 705-717.

El-Sayed, Boshra, A.; El-Fouly, Aml, S.A. and ElFeky, A.H. (2008). Response of Ficus macrocarpa L. var "Hawaii" transplants to some fertilization treatments Egypt J. of Appl., Sci., 23 (1): 224-231.

El-Sayed, Boshra, A.; El-Fouly, Aml, S.A. and Shahin, S.M. (2013). Response of Spindle tree (Euonymus japonicus Thunb cv. Aureus) plant to some growing media. J. Boil Chem. \& Environ. Sci., 8 (3): 61-71.
El-Sayed, Boshra, A. and El-Shal, S.A. (2008). Effect of growing media and humic acid on schefflera quality. J. Agric. Sci., Mansoura univ., 33 (1): 371-381.

Gonzalez, R. F. and Cooperband, L.R. (2003). Compsot effects on soil chemical properties and field nursery production. J. Environ. Hort., 21 (1): $38-44$.

Hammad, H.H.; Eliwa, Nagla, L.Y. and Mohamed, T.A. (2005). Growth of Ceratonia siliqua L. (Carob) seedlings as affected by different growing media and nitrogen fertilization. The $6^{\text {th }}$ Arabian Conf. Hort., Ismailia, Egypt: 87-97.

Handreck, K. and Black, N (2002). Growing Media for Ornamental Plants and Turf. $3^{\text {rd }}$ Ed., Univ. New Wales Press Ltd., Sydney, Australia, 542 pp.

Helmut, G. (1976). Etymologisches Worterbuch der Botanischen Pflanzennamen, ISBN 3-76430755-2.

Luatanab, F. S. and Olsen, S. R. (1965). Test of an ascorbic acid method for determining phosphorus in water and $\mathrm{NaHCO} 3$ extracts from soil. Soil Sci. Soc. Amer. Proc., 29: 677-678.

Marfa, L.O.; Caceres, R.; Giuffrida, F. and Guerin, V. (2002). Relationships between growing media fertility, percolate composition and fertigation strategy in peat-substitute substrates used for growing ornamental shrubs. Scientia Hort., 94 (3/4): 309-321.

Mashinchian, M.; Kafi, M. and Kalatekjari, S. (2017). Effects of expanded clay (Leca) and styrofoam as inorganic growing media substances on growth and development of Spathiphyllum wallisii. Wizanamah Persian J., 27-33.

Massa, D.; Malorgio, F.; Lazzereschi, S.; Carmassi, G.; Prisa, D. and Burchi, G. (2018). Evaluation of two green composts for peat substitution in geranium (Pelargonium zonale L.) cultivation: Effect of plant growth, quality, nutrition and photosynthesis. Scientia Hort., 228: 213-221.

Mead, R.; Curnow, R. N. and Harted, A. M. (1993). Statistical Methods in Agriculture and Experimental Biology. $2^{\text {nd }}$ Ed., Chapman \& Hall Ltd., London, 335 pp.

Mohamed, Y.F.Y. (2018). Influence of different growing media and kristalon chemical fertilizer on growth and chemical composition of Areca palm (Dypsis cabadae H. E. Moore) plant. Middle East J. Appl. Sci., 8 (1): 43-56.

Nieto, A.; Gasco, G; Paz-ferreiro, J.; Fernandez, J. M.; Plaza, C. and Mendez, A. (2016). The effect of pruning waste and biochar addition on brown peat based growing media properties. Scientia., Hort. 199: 142-148. 
Niluni, B. Z.; Wijesundara, M.; Abbey, L. and Rupasinghe, H.P.V. (2017). Growing medium amendments effect on growth, secondary metabolites and antistreptococcal activity of two species of Plectranthus. J. Appl. Res. on Medicinal and Aromatic plants, 5: 53-59.

Page, A.L.; Miller, R.H. and Keeny, D.R. (1982). Methods of Soil Analysis, Part II., 2 ${ }^{\text {nd }}$ Ed., Agronomy Monogr., ASA and SSSA, Madison, W.I.

SAS, Institute. (2009). SAS/STAT User's Guide, Statistics. Vers. 6.04, $4^{\text {th }}$ Ed., SAS. Institute Inc. Cary, N.C., USA.

Sax, M.S. and Scharenbroch, B.C. (2017). Assessing alternative organic amendments as horticultural substrates for growing trees in containers. J. Environ. Hort., 35 (2): 66-78.

Shahin, S.M.; Eliwa, Nagla, Y. and El-Sayed, Boshra, A. (2007). Growth, flowering and chemical composition of Hibiscus rosa-sinensis L. transplants as affected by foliar spray with two forms of potassein. J. Biol. Chem. \& Environ. Sci., 2 (4): 151-165.
Shahin, S.M.; El-Tayeb, H.F. and El-Sayed, Boshra, A. (2012). Effect of some media and fertilization treatments on growth and quality of some foliage pot plants. J. Biol. Chem. \& Environ., Sci., 7 (1): 93-112.

Shahin, S.M.; El-Sayed, Boshra, A. and El-Tayeb, H.F. (2014). Improving growth and quality of Merremia dissecta (Jacq.) H.G. Hallier twiner by some fertilization treatments. Alex J. Agric. Sci., 59 (1): 43-49.

Steel, R. G. D. and Torrie, J. H. (1980). Principles and Procedures of Statistics. McGraw Hill Book Co., Inc., New York, P: 377-400.

Sumathi, T.; Chawla, S.L.; Patil, S. and Palagani, N. (2017). Effect of growing media and primary nutrients on postharvest life of cut flowers of anthurium var. Tropical. J. Ornam. Hort., 20 (1 \& 2): 75-79.

Wazir, M.G.; Amin, N.; Khan, I. and Khan, F.M. (2004). Effect of different potting mixtures and nitrogen sources on the performance of Brassaia seedlings. Sarhad J. Agric., 20 (1): 25-31.

Yadava, Y. L. (1986). Rapid and non-destructive methods to determine chlorophyll in intact leaves. HortScience, 21: 1449-1450. 


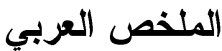

\section{إستجابة نباتات البرواليا والتيفتيا الصفراء لبعض بيئات النمو ومعاملات التسميا}

\author{
سبا محمد شاهين وعبلة حسن درغام \\ قسم بحوث الحدائق النباتية، معهد بحوث البساتين، مركز البحوث الزر اعية، الجيزة، مصر
}

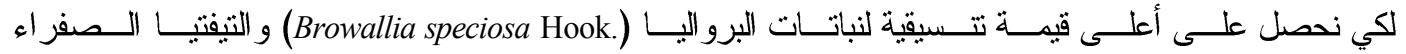

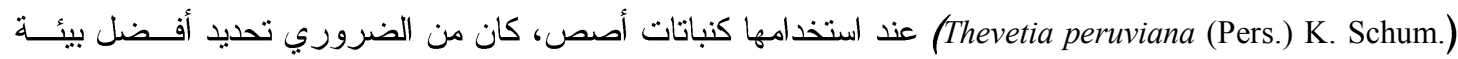
ومعاملة سمادية للحصول على أفضل نمو. لذلك أجريت هذه الدر اسة بمكان نصف مظلل بمشتل حديقــة الأورمــان

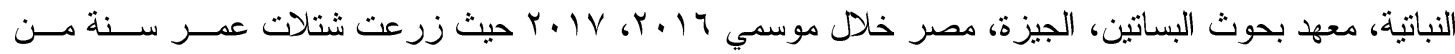

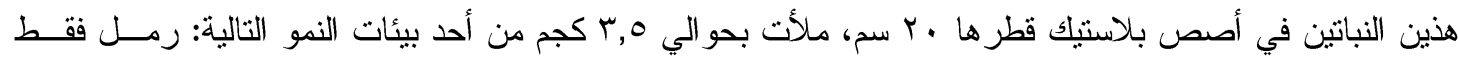

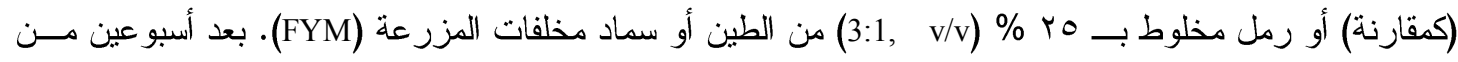

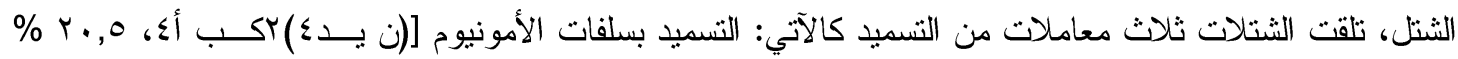

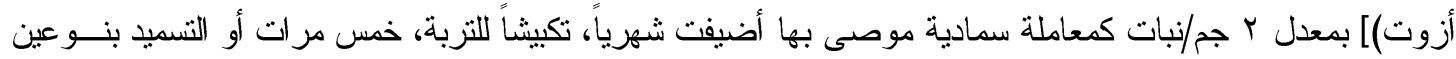

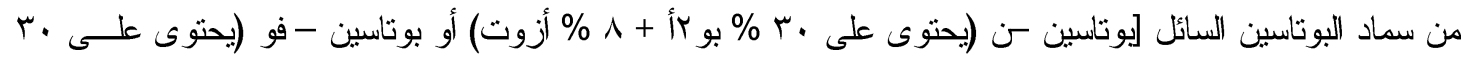

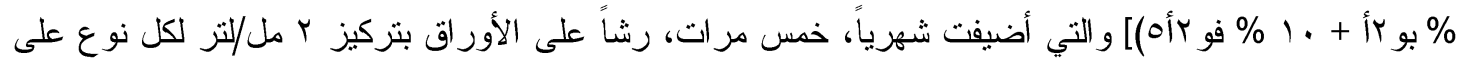

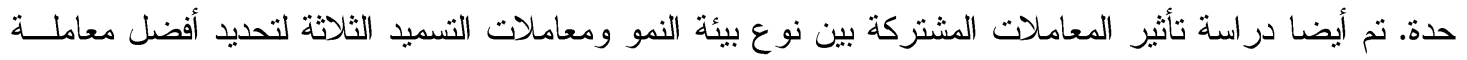
بيئية سمادية لنمو هذين النباتين في أصص.

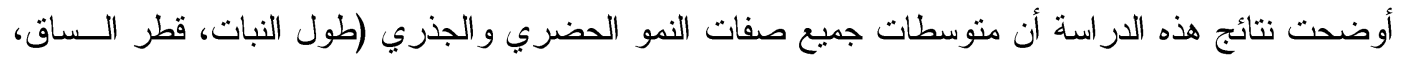

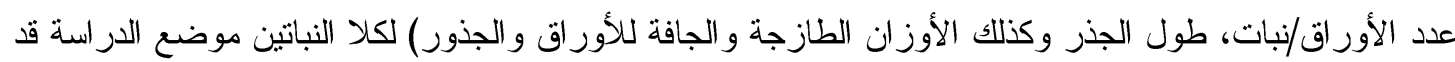

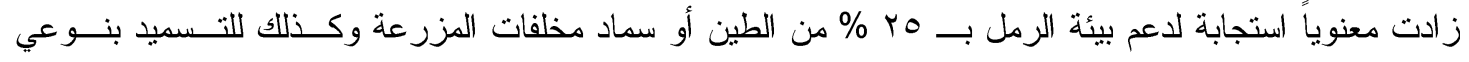

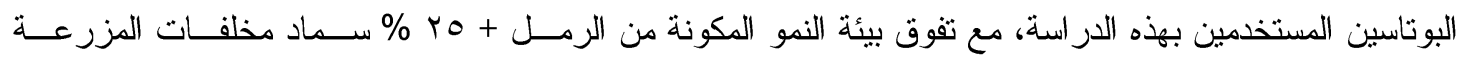

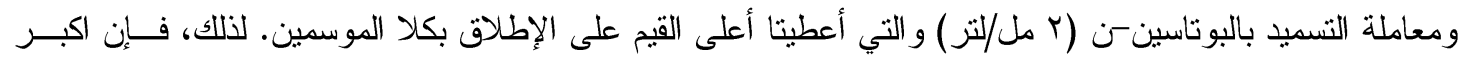

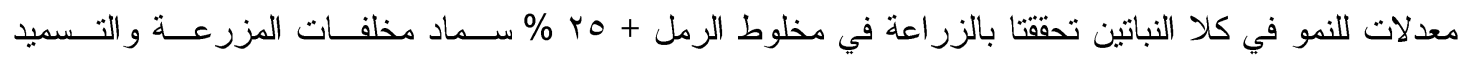

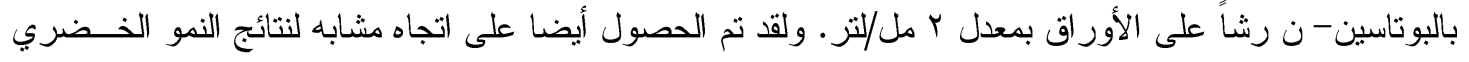

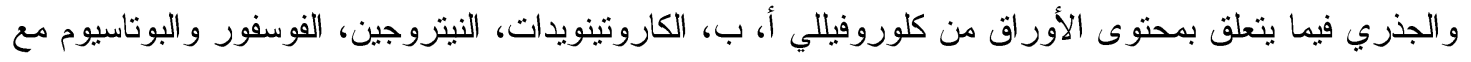
بعض الاستثناءات البسيطة. طبقاً لهذه النتائج، يمكن التوصية بزر اعة الثتلات عمر سنة لنباتي البرو اليا و التيفتيا الصفر اء في مخلوط نمــو

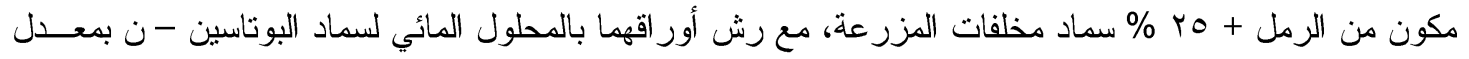

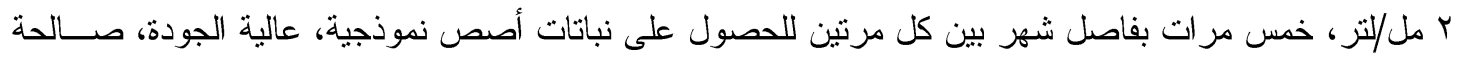
للنسويق التجاري. 